TOMISLAV KLJAK, M.Sc.

E-mail: tomislav.kljak@fpz.hr

University of Zagreb,

Faculty of Transport and Traffic Sciences

Vukelićeva 4, 10000 Zagreb, Croatia

MARIJAN BOLARIĆ, Ph.D.

E-mail: marijan.bolaric@posta.hr

MARIJAN BINIČKI, M.

E-mail: marijan.binicki@posta.hr

Croatian Post

Branimirova 4, 10000 Zagreb, Croatia
Information and Communication Technology Preliminary Communication Accepted: Oct. 22, 2010 Approved: July 6, 2011

\title{
IMPACT OF MOBILE TELECOMMUNICATIONS TRAFFIC ON THE DEVELOPMENT OF POSTAL TRAFFIC
}

\begin{abstract}
The key hypothesis of the paper is the existence of a particular impact occurring between the development of mobile telecommunications traffic and the development of postal traffic. The objective of the paper is to ascertain the strength of the impact as well as the nature (type) of the impact in the case of the state of the art in the Republic of Croatia. Relevant data have been collected regarding the number of postal services realised (letters and parcels), minutes referring to duration of the voice conversations within, from and towards mobile networks as well as the number of text messages (SMSs) sent. The interrelations between the postal traffic and mobile telecommunications traffic have been determined following the multi-regression linear modelling which has been statistically tested after having been determined.
\end{abstract}

\section{KEY WORDS}

postal traffic, multi-regression modelling, mobile telecommunications traffic

\section{INTRODUCTION}

It is a well known historical fact that the development of telecommunications has been fostered and enabled via postal companies (starting with the telegraphy and telephony which were introduced as support services for the faster transfer of letter mails). Today, similar example is the e-mail which utilizes the overall postal terminology so as to be more acceptable to the users. However, the present and the future development of telecommunications presents a particular threat to the viability of classical physical forms of communication. A question arises here as to how much these forecasts and visions are correct. Can particular patterns and rules be defined in relation to the impact of specific communication technologies? In this respect this paper focuses on mobile communications as significantly widespread and well accepted forms of communication (as opposed to telecommunication traffic generated from informatics which requires larger financial investments into the purchase of technical devices as well as higher level of operational knowledge for the usage of such devices).

\section{TYPES OF INTERACTIONS AMONG TECHNOLOGIES}

According to the results of interactions occurring due to the arrival of new technologies, they may be divided into four groups, i.e. types:

- substitution,

- complementarity,

- stalling,

- creation of a new demand.

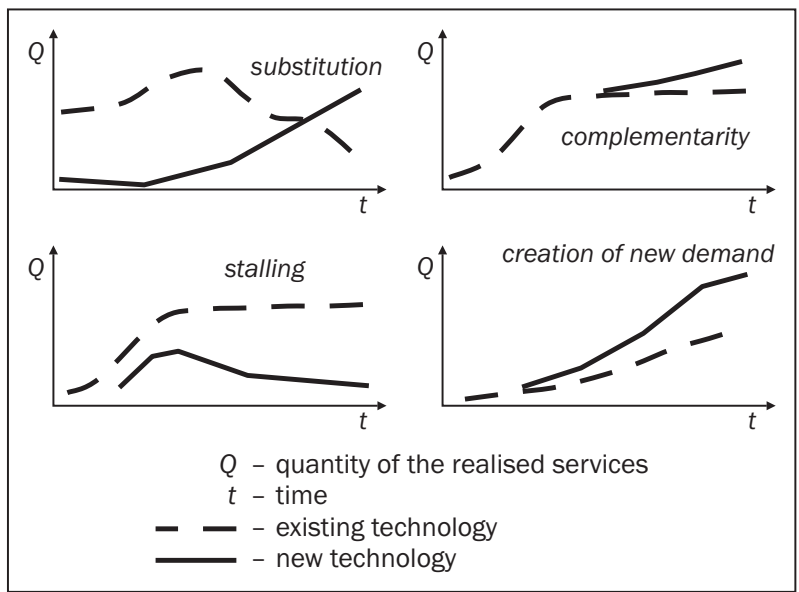

Figure 1 - Types of interaction between the existing and new technology [1] 
As indicated in Figure 1 the following specific situations (consequences) are to be taken into consideration:

- In case of substitution the overall elimination of old technologies is expected which will be followed by the introduction of new technologies in due time.

- In case of the complementarity of the technologies, both technologies are developed without being interrupted by each other, while the space for positive indirect impacts is also being created.

- As new technologies in the initialization phase show tendency to grow and take over a more significant status on the market, and after a certain period of time start bating, new technologies remain at stalling.

- The last situation refers to the case in which the new technology appears or causes the creation of a completely new demand which does not affect the existing technology.

In case of postal traffic there is an entire set of forecasts (such as [2], [3], [4]) provided by experts and institutions who, upon the emergence of electronic communications, readily announced quite prompt and complete substitution of the physical transfer of consignments as evolutional necessity further to the entire range of useful effects (speed, security, ecology, and similar). However, this has not been realised so far, while on the other side, these "young" and "new" information-telecommunications technologies already indicate their shortcomings (ecological: technical waste management, energy consumption, heating as a consequence of device operations, $\mathrm{CO}_{2}$ production, etc.; sociological: resistance by certain social communities; economical: significant investments, constant development and maintenance, uneven development of countries; huge energy dependence; security vulnerability and similar). So, where are we now?

\section{FACTORS OF IMPACT}

Factors affecting the size of the realised postal traffic vary rather a lot and with a different impact level depending on the area subject to the observation. Subsequently it is hardly possible to set one applicable general model of the hierarchy of impact factors, but rather for each area in the world a relevant list of impacts by individual factors (variables) is defined. In this respect the factors may be divided into those which may be affected by postal operators (quality of the service and similar) - i.e. postal factors, and those which cannot be affected by postal operators (population policy) - economic, sociological and technological factors.

Further below the results of the survey conducted by the world postal association are outlined and elabo- rated. The survey followed the method of pooling the post administrations throughout the world. The data should not be perceived or interpreted as being determining or permanent, since they unambiguously change to a lesser or larger extent as a sound basis for outlining the complexity and looking for the potential ways or efficient methods for high-quality forecasting of further development of postal traffic, i.e. demand for postal services. Figure 2 shows the distribution of basic groups of factors in accordance with the point of view and data collected from post administrations throughout the world [5].

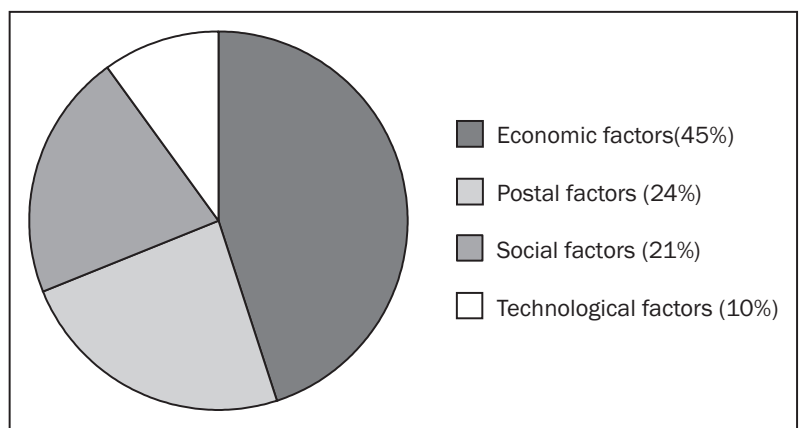

Figure 2 - Breakdown of impacts per types of factors at the level of the whole world [5]

Based on Figure 2, the dominating impact may be noticed regarding economic factors followed by postal factors which are also significant at the level of sociological factors. It should be stressed here that the sole technological impact, which in this survey is of primary significance, actually bears the least of the impact as opposed to other types. However, this breakdown varies significantly depending on the area of subject to observations and therefore below is a short analysis of each individual group of factors per regions, where priorities will rank differently (i.e. in Africa the priorities relate to socio-demographic factors, while in the developed West the priorities relate to technological and postal priorities), as presented in Figure 3.

\section{EXAMPLES OF APPLYING REGRESSION MODELS TO POSTAL TRAFFIC FORECASTS}

Various expert studies focused on the elaboration of models which included a larger number of independent volumes. Therefore, a common and general form of linear regression equation representing the dependence of the quantity of postal services on several key factors relating to economic indicators, features of postal services, demographic specifics and potential substitutions leads to:

$$
\begin{aligned}
& \text { service }_{i}=\alpha+\beta_{i} \mathrm{GDP}_{i}+\beta_{2} \text { price }_{i}+ \\
& \quad+\beta_{3} \text { demographics }_{i}+\beta_{4} \text { quality }_{i}+ \\
& +\beta_{5} \text { substitutes }_{i}+\varepsilon_{i}
\end{aligned}
$$




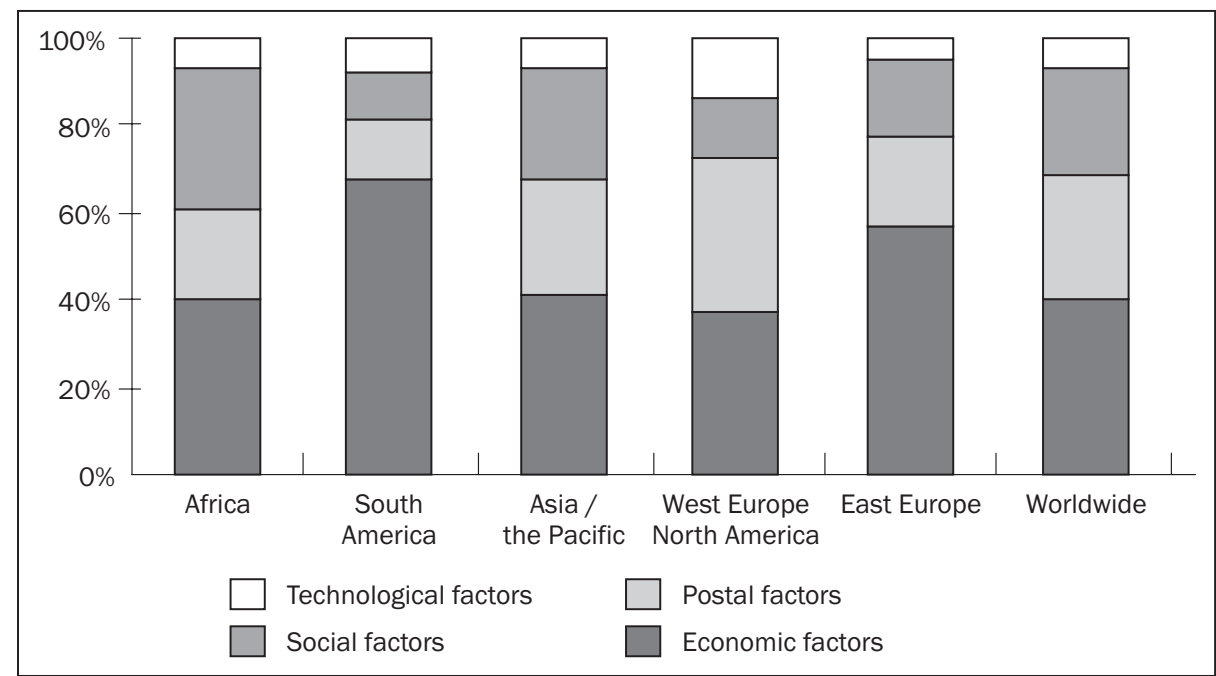

Figure 3 - Breakdown of significance of impacts per individual types of factors depending on the region [5]

The strength of the impact of individual factors is expressed by coefficients $\left(\beta_{i}\right)$ while element $\varepsilon_{i}$, represents the remaining item. However, there are numerous ways in which an individual factor may be expressed, i.e. in relation to what has been followed. For example, GDP is perceived as an indicator of economic activities since the majority of postal traffic is generated from business users. On the basis of the abovementioned further differentiation is enabled with regards to what types of business users are specifically taken into consideration (financing sector, production sector, sales and similar). Afterwards, each of these sectors is accompanied by adequate coefficients of impacts. The same observation applies to other basic groups of factors included in Equation 1.

Numerous studies have been performed in the last ten years and it is quite interesting to observe them as regards to how the individual experts used and adjusted the input data and specifications of models in order to highlight a particular aspect [6]. However, all of them regularly ended up with similar results and all of these adjustments or approaches did not show significant deviations or differences in relation to the basic rules or patterns regarding modelling the demand for postal services.

At the same time, models were elaborated which focused on the demand for postal services from industry sector. Therefore Izutsu and Yamaura set the following regression equation [7]:

$$
\begin{gathered}
\text { service }_{i j}=\alpha+\beta_{i}(\# f a x)_{i j}+\beta_{2}(\# P C)_{i j}+ \\
+\beta_{3}(\# p h o n e)_{i j}+\beta_{4}(\# s a l e s)_{i j}+ \\
+\beta_{5}(\# \text { (\#mployees })_{i j}+\varepsilon_{i}
\end{gathered}
$$

analysing the demand for postal services for each company $i$ belonging to the industry sector $j$. However, this survey did not provide completely reliable conclusions although researchers claimed a positive correlation between positive impacts on the demand. Still, the fact remains that the impact of fax machines de- creases, while on the other side the model does not include the factor of the price for the service at all (either postal or the potentially substituting services), and this represents an important item in the business environment with respect to reaching decisions on the selection of communication media.

Some authors, such as Wolak [8], [9], followed the regression model outlined below into which he introduced the MAX function. This function excludes from the database all the data relating to persons not generating any postal traffic whatsoever:

$$
\begin{aligned}
& \text { service }_{i j}=\operatorname{MAX}\left\{\alpha+\beta_{i}(\text { fax })_{i j}+\beta_{2}(P C)_{i j}+\right. \\
& \left.\quad+\beta_{3} \text { (network }\right)_{i j}+\beta_{4}(\text { phone })_{i j}+ \\
& \left.\quad+\beta_{5} \text { (members }\right)_{i j}+\beta_{6}(\text { age })_{i j}+ \\
& \left.\quad+\beta_{7}(\text { occupation })_{i j}+\beta_{8}(\text { income })_{i j}+\varepsilon_{i}, 0\right\}
\end{aligned}
$$

Similar to the above, Santos and Lagao [10] conducted a research in Portugal encompassing $131 \mathrm{com}$ panies. They set the limit for inclusions into the model expressing it by annual financial business activities. Consequently, only the companies which earned higher incomes than the specified amount were analysed:

$$
\begin{aligned}
& \text { service }_{i j}=\alpha+\beta_{i}(\text { price })_{i}+\beta_{2}(\text { labor })_{i}+\beta_{3}(\text { sales })_{i}+ \\
& \quad+\beta_{4}(\text { assets })_{i}+\beta_{5}(\text { insurance })_{i}+\beta_{6}(T V)_{i}+ \\
& \quad+\beta_{7}(\text { outdoors })_{i}+\beta_{8}(\text { unaddressed })_{i}+ \\
& \quad+\beta_{9}(\text { telemarketing })_{i}+\beta_{10}(\text { sponsorship })_{i}+ \\
& \quad+\beta_{11}(\text { Internet })_{i}+\beta_{12}(\text { adverts })_{i}+ \\
& \quad+\beta_{13}(\text { years })_{i}+\varepsilon_{i}
\end{aligned}
$$

\section{CASE STUDY OF THE REPUBLIC OF CROATIA}

Through the survey secondary data were collected on three variables which for the Republic of Croatia comprise the following:

- the number of the realised postal services (letters and packages) (data collected at the website of the Republic of Croatia State Statistics Bureau) [11]; 
Table 1 - Input data and auxiliary calculations

\begin{tabular}{|c|c|c|c|c|c|c|c|c|c||}
\hline Year & Postal services & Number of SMSs & $\begin{array}{c}\text { Minutes within/ } \\
\text { from mobile } \\
\text { networks }\end{array}$ & {$\left[\times 10^{17}\right]$} & {$\left[\times 10^{17}\right]$} & {$\left[\times 10^{18}\right]$} & {$\left[\times 10^{17}\right]$} & {$\left[\times 10^{18}\right]$} & {$\left[\times 10^{18}\right]$} \\
\hline & $y_{i}$ & $x_{i 1}$ & $x_{i 2}$ & $x_{i 1} y_{i}$ & $x_{i 2} y_{i}$ & $x_{i 1} x_{i 2}$ & $y_{i}{ }^{2}$ & $x_{i 1}{ }^{2}$ & $x_{i 2}{ }^{2}$ \\
\hline \hline 2002 & $323,319,000$ & $1,660,696,400$ & $1,247,940,500$ & 5.369 & 4.035 & 2.072 & 1.045 & 2.758 & 1.557 \\
\hline 2003 & $342,057,000$ & $2,025,660,500$ & $1,730,458,000$ & 6.929 & 5.919 & 3.505 & 1.170 & 4.103 & 2.994 \\
\hline 2004 & $348,389,000$ & $2,243,216,000$ & $2,041,710,000$ & 7.815 & 7,113 & 4.580 & 1.214 & 5.032 & 4.169 \\
\hline 2005 & $374,931,000$ & $2,359,614,000$ & $2,675,176,000$ & 8.847 & 10.030 & 6.312 & 1.406 & 5.568 & 7.157 \\
\hline 2006 & $398,947,000$ & $2,510,524,000$ & $3,981,572,000$ & 10.016 & 15.884 & 9.996 & 1.592 & 6.303 & 15.853 \\
\hline 2007 & $405,903,000$ & $2,724,320,450$ & $4,887,376,400$ & 11.058 & 19.838 & 13.315 & 1.647 & 7.422 & 23.886 \\
\hline \hline & $2,193,546,000$ & $13,524,031,350$ & $16,564,233,400$ & $\begin{array}{c}5.0034 \\
\times 10^{18}\end{array}$ & $\begin{array}{c}6.2819 \\
\times 10^{18}\end{array}$ & $\begin{array}{c}3.9780 \\
\times 10^{19}\end{array}$ & $\begin{array}{c}8.0740 \\
\times 10^{17}\end{array}$ & $\begin{array}{c}3.1186 \\
\times 10^{19}\end{array}$ & $\begin{array}{c}5.5616 \\
\times 10^{19}\end{array}$ \\
\hline \hline
\end{tabular}

- the number of text messages (SMSs) sent (data collected at the website of the Croatian Post and Electronic Communication Agency - HAKOM, "The overview of traffic and financial data of the electronic communication market in the Republic of Croatia for the period 2002 - 2007") [12];

- the overall sum of minutes within and between mobile networks and towards fixed networks (data collected at the website of the Croatian Post and Electronic Communication Agency - HAKOM, "The overview of traffic and financial data of the electronic communication market in the Republic of Croatia for the period 2002 - 2007") [12].

The objective is to set a model of impacts of mobile telecommunication traffic on the size of postal traffic realised on the basis of data collected for the period of years from 2002 to 2007 by using linear multi-regression modelling [13].

It is assumed in this case that for setting a model on the demand for postal services two variables are sufficient (the number of text messages within the mobile network and minutes of phone calls within and between mobile networks or towards fixed networks). This dependence is expressed through the assumed model of multi-linear regression (additive type) referring to a general case:

$$
y_{i}=\alpha+\beta_{1} x_{i 1}+\beta_{2} x_{i 2}+\varepsilon_{i}, \quad i=1,2, \ldots, n
$$

The estimates of parameters following the method of the lowest squares present the solution to the system of normal equations which are in general form for $\mathrm{K}=2$ ( $\mathrm{K}$ is the number of independent variables):

$$
\begin{aligned}
& \hat{\alpha} n+\hat{\beta}_{1} \sum_{i=1}^{n} x_{i 1}+\hat{\beta}_{2} \sum_{i=1}^{n} x_{i 2}=\sum_{i=1}^{n} y_{i} \\
& \hat{\alpha} \sum_{i=1}^{n} x_{i 1}+\hat{\beta}_{1} \sum_{i=1}^{n} x_{i 1}^{2}+\hat{\beta}_{2} \sum_{i=1}^{n} x_{i 1} x_{i 2}=\sum_{i=1}^{n} x_{i 1} y_{i} \\
& \hat{\alpha} \sum_{i=1}^{n} x_{i 2}+\hat{\beta}_{1} \sum_{i=1}^{n} x_{i 2} x_{i 1}+\hat{\beta}_{2} \sum_{i=1}^{n} x_{i 2}^{2}=\sum_{i=1}^{n} x_{i 2} y_{i}
\end{aligned}
$$

After including the amounts gained in the previous table (Table 1) the amount equals:

$$
\begin{aligned}
& 6 \hat{\alpha}+13,524,031,350 \hat{\beta}_{1}+ \\
& +16,564,233,400 \hat{\beta}_{2}=2,193,546,000 \\
& 13,524,031,350 \hat{\alpha}+3.1186 \cdot 10^{19} \hat{\beta}_{1}+ \\
& +3.9780 \cdot 10^{19} \hat{\beta}_{2}=5.0034 \cdot 10^{18} \\
& 16,564,233,400 \hat{\alpha}+3.9780 \cdot 10^{19} \hat{\beta}_{1}+ \\
& +5.5616 \cdot 10^{19} \hat{\beta}_{2}=6.2819 \cdot 10^{18}
\end{aligned}
$$

Solving of the above system with three unknown elements results in the following estimates of parameters:

$$
\begin{gathered}
\hat{\alpha}=253,580,661.4 ; \quad \hat{\beta}_{1}=0.031086141 ; \\
\hat{\beta}_{2}=0.015192498
\end{gathered}
$$

Regression model (equation) with such estimated parameters follows as:

$$
\begin{aligned}
\hat{y}= & 253,580,661.4+0.031086141 x_{1}+ \\
& +0.015192498 x_{2}
\end{aligned}
$$

On the basis of the resulting values of parameters of each independent variable it may subsequently be noticed that their value is positive. This explains the fact that there is no substitution impact on the depending variable, i.e. postal services. Simultaneously, both values are relatively low and it may be concluded that not even a positive impact in respect to the increase of postal services is so impressive. These results are in accordance with earlier observations of distinctive impacts of individual factors.

After defining the regression equation it is possible and useful to define a standard deviation and a coefficient of variations for this equation. Including the known values for independent variables $x_{1}$ and $x_{2}$ into the resulting regression equation, regression values are calculated (theoretical values in accordance with the model). Afterwards, residual deviations result from comparing the actual (known) values of the dependent variable $y$ with the calculated regression values (Table 2).

The general calculation of the standard deviation of multi-regression amounts to: 
Table 2 - Regression values and accompanying residual deviations

\begin{tabular}{||c|c|c|c|c||}
\hline \hline Year & Postal services & Regression values & Residual deviations & $\begin{array}{c}\text { Relative residual } \\
\text { deviations }\end{array}$ \\
\hline & $y_{i}$ & $\hat{y}_{i}$ & $\hat{e}_{i}=y_{i}-\hat{y}_{i}$ & $\hat{e}_{i, \text { rel }}=\frac{y_{i}-\hat{y}_{i}}{y_{i}} 100$ \\
\hline \hline 2002 & $323,319,000$ & $324,164,637.4$ & $-845,637.4$ & -0.2615148934 \\
\hline 2003 & $342,057,000$ & $342,840,616.6$ & $-783,616.6$ & -0.2290894790 \\
\hline 2004 & $348,389,000$ & $354,332,265.4$ & $-5,943,265.4$ & -1.7059279710 \\
\hline 2005 & $374,931,000$ & $367,574,560.9$ & $7,356,439.1$ & 1.9620781160 \\
\hline 2006 & $398,947,000$ & $392,113,189.1$ & $6,833,810.9$ & 1.712962098 \\
\hline 2007 & $405,903,000$ & $412,520,727.2$ & $-6,617,727.2$ & -1.630371591 \\
\hline
\end{tabular}

$\sigma_{\hat{y}}=\sqrt{\frac{\sum_{i=1}^{n}\left(y_{i}-\hat{y}_{i}\right)^{2}}{n}}$

i.e.:

$\sigma_{\hat{y}}=\sqrt{\frac{\sum_{i=1}^{n} y_{i}^{2}-\hat{\alpha} \sum_{i=1}^{n} y_{i}-\hat{\beta}_{1} \sum_{i=1}^{n} x_{i 1} y_{i}-\hat{\beta}_{2} \sum_{i=1}^{n} x_{i 2} y_{i}-\ldots-\hat{\beta}_{k} \sum_{i=1}^{n} x_{i k} y_{i}}{n}}$

Particularly in this analysis the formula takes the form of:

$\sigma_{\hat{y}}=\sqrt{\frac{\sum_{i=1}^{n} y_{i}^{2}-\hat{\alpha} \sum_{i=1}^{n} y_{i}-\hat{\beta}_{1} \sum_{i=1}^{n} x_{i 1} y_{i}-\hat{\beta}_{2} \sum_{i=1}^{n} x_{i 2} y_{i}}{n}}$

and equals:

$=\sqrt{\frac{8.0740 \cdot 10^{17}-253,580,661.4 \cdot 2,193,546,000-}{6}}$

$\sqrt{-0.031086141 \cdot 5.0034 \cdot 10^{18}-}$

$\sqrt{\frac{-0.015192498 \cdot 6.2819 \cdot 10^{18}}{}}=$

$=\sqrt{\frac{0.001863 \cdot 10^{17}}{6}}=5,572,396.253$

Variation coefficient amounts to:

$v_{\hat{y}}=\frac{\sigma_{\hat{y}}}{\bar{y}} \cdot 100=\frac{5,572,396.253}{\frac{2,193,546,000}{6}} \cdot 100=1.52416[\%]$

Therefore, the standard deviation of the resulting regression equation amounts to $\pm 5,572,396.253$ of postal services, while the variation coefficient amounts to $1.52 \%$.

In the case in which the regression model is analysed in the framework of inferential statistics (and not within descriptive statistics as previously assumed), the denominator of the formula for standard deviation is changed. Subsequently, the formula follows as shown below:

$\hat{\sigma}=\sqrt{\frac{\sum_{i=1}^{n} y_{i}^{2}-\hat{\alpha} \sum_{i=1}^{n} y_{i}-\hat{\beta}_{1} \sum_{i=1}^{n} x_{i 1} y_{i}-\hat{\beta}_{2} \sum_{i=1}^{n} x_{i 2} y_{i}-\ldots-\hat{\beta}_{K} \sum_{i=1}^{n} x_{i k} y_{i}}{n-(K+1)}}$
In the case above, the values resulting would follow as:

$=\sqrt{\frac{8.0740 \cdot 10^{17}-253,580,661.4 \cdot 2,193,546,000-}{6-(2+1)}}$

$\sqrt{-0.031086141 \cdot 5.0034 \cdot 10^{18}-}$

$\sqrt{\frac{-0.015192498 \cdot 6.2819 \cdot 10^{18}}{}}=$

$=\sqrt{\frac{0.001863 \cdot 10^{17}}{3}}=7,882,385.426$

While the variation coefficient equals:

$\hat{v}=2.156[\%]$

\section{TESTING THE SIGNIFICANCE OF THE RESULTING MODEL}

The resulting regression model bears rather insignificantly concrete analytical meaning without the judgement on its quality, which is defined by testing. A number of various tests exist. However, the most commonly used are the following:

- test of the regression significance, i.e. group test (defining the significance of the presence of all explanatory variables/parameters in the model);

- test of the significance of an individual parameter (individual explanatory variables in the model), i.e. individual test;

- test of the significance of parameter subgroup, i.e. partial test;

- coefficient of the multiple linear determination (indicating the percentage of the interpreted variations through the model) [13].

For testing the resulting model for forecasting postal traffic depending on mobile communications a group test was used, following standard hypotheses:

$\left.\begin{array}{l}\mathrm{H}_{0}: \beta_{1}=\beta_{2}=\ldots=\beta_{j}=\ldots=\beta_{K}=0 \\ \mathrm{H}_{1}: \exists \beta_{j} \neq 0\end{array}\right\} j=1,2, \ldots, K$

The zero hypothesis $\left(\mathrm{H}_{0}\right)$ claims that not even a single variable in the regression model bears significance; 
T. Kljak, M. Bolarić, M. Binički: Impact of Mobile Telecommunications Traffic on the Development of Postal Traffic

Table 3 - Model input data and auxiliary calculations for the implementation of group test of multi-regression model

\begin{tabular}{||c|c|c|c|c|c|c||}
\hline \hline Year & Postal services & Regression values & $\begin{array}{c}\text { Residual } \\
\text { deviations }\end{array}$ & & \\
\hline & $y_{i}$ & $\hat{y}_{i}$ & $y_{i}-\hat{y}_{i}$ & $\begin{array}{c}\left(y_{i}-\hat{y}_{i}\right)^{2} \\
{\left[\times 10^{11}\right]}\end{array}$ & $\hat{y}_{i}-\bar{y}$ & $\begin{array}{c}\left(\hat{y}_{i}-\bar{y}\right)^{2} \\
{\left[\times 10^{12}\right]}\end{array}$ \\
\hline \hline 2002 & $323,319,000$ & $324,164,637.4$ & $-845,637.4$ & 7.151 & $-41,426,362.6$ & 171.614 \\
\hline 2003 & $342,057,000$ & $342,840,616.6$ & $-783,616.6$ & 6.141 & $-22,750,383.4$ & 51.758 \\
\hline 2004 & $348,389,000$ & $354,332,265.4$ & $-5,943,265.4$ & 353.224 & $-11,258,734.6$ & 12.676 \\
\hline 2005 & $374,931,000$ & $367,574,560.9$ & $7,356,439.1$ & 541.172 & $1,983,560.9$ & 3.935 \\
\hline 2006 & $398,947,000$ & $392,113,189.1$ & $6,833,810.9$ & 467.010 & $26,522,189.1$ & 70.343 \\
\hline 2007 & $405,903,000$ & $412,520,727.2$ & $-6,617,727.2$ & 437.943 & $46,929,727.2$ & 220.240 \\
\hline \hline & $2,193,546,000$ & $2,193,546,000$ & $0(-3.4)$ & $1.8126 \times 10^{14}$ & & $53.5066 \times 10^{14}$ \\
\hline
\end{tabular}

in other words, all parameters concerning explanatory variables equal zero. The alternative hypothesis brings the opposite claim, i.e. there is at least one out of $\mathrm{K}$ explanatory variables which is significant for explaining the variability of the depending variable (i.e.: that at least one of the parameters of explanatory variables differs from zero).

Testing size is the empirical F-ratio and it is calculated as follows:

$$
F=\frac{\sum_{i=1}^{n}\left(\hat{y}_{i}-\bar{y}\right)^{2} / K}{\sum_{i=1}^{n}\left(y_{i}-\hat{y}_{i}\right)^{2} /[n-(K+1)]}
$$

The numerator of the ratio is the explained mean value of the square, while the denominator is the residual mean value of the square (the estimation of the variance). If a model is tested at the level of significance $\alpha$, a decision is brought by comparing empirical test size and theoretical value of F-distribution. The scope of accepting the zero hypothesis is as follows:

$$
F<F_{\alpha,[K, n-(K+1)]}
$$

Further below a test of quality is performed with regards to previously set regression model which follows the changes in the number of postal services depending on mobile telecommunications. For the needs of a group test it is possible that a part of data is used comprising the data previously calculated with respect to defining residual deviations (from Table 2).

$$
\begin{array}{r}
\bar{y}=\frac{2,193,546,000}{6}=365,591,000 \\
F=\frac{53.0566 \cdot 10^{14} / 2}{1.8126 \cdot 10^{14} / 6-(2+1)}=43.906
\end{array}
$$

Taking into account the assumed level of significance amounting to $5 \%$ ( $\alpha=0.05$ ), the value of theoretical F-ratio for this situation equals: $F_{0.05[2,3]}=9.55$ which is less than the empirical F-ratio, $F=43.906$ resulting in the rejection of the zero hypothesis.

$$
F>F_{0.05[2,3]} \rightarrow H_{0} \text { rejected. }
$$

The above mentioned provides the justification for the basic quality of the set multi-linear regression model which establishes the connections between the development of postal traffic services and the development of mobile communications services.

\section{CONCLUSION}

Throughout the six-year-period which was followedup and modelled, a relatively small but positive impact of mobile telecommunications traffic on the development of postal traffic is shown. This leads to the conclusion that the assumption of the hazards of substituting postal traffic with telecommunications technologies can be negligible. The thesis analyses only one of the telecommunications technologies, which is currently the strongest and characterized by the highest rates of growth and development and therefore particularly interesting. Similar methodological approach may also be followed in performing the analyses for other electronic communication alternatives (fixed, informatics, radio, TV, hybrid, ad-hoc and similar).

Some of the potential reasons for such result arise from the fact that SMS traffic is a greater threat to mobile voice traffic than to postal traffic (because of tariffs, type of transferred information, etc.). In short, historically, the "damage" to postal traffic from the telecommunication traffic was already done years and years ago with wider exploitation of telephony. Now, there is only switch from fixed to mobile telephony without serious impact on postal traffic in general. There are also social factors (time to adopt new technologies, trust, reliability, etc.), wide spreading of technology (post has full world coverage), simplicity (direct access since for postal communication there is no need for any kind of technical devices support), ecological (e-waste from hardware components, energy consumption and dependence upon it, etc.). On the other side, with mobile telecommunications postal traffic has the opportunity for enriching of the existing services and innovation 
of the new ones (as hybrid mail, intelligent mail and similar). All those considerations are subject to further research.

This survey proves the existence of the current relationship between mobile telecommunication technologies, i.e. traffic and postal traffic. It should be highlighted here that the substitution is not "at the doors" while the outstanding issue remains whether the substitution would ever be real or possible. The above described methodological procedure may be further followed up in a relatively simple way and the state of the art may be analyzed. A more detailed analysis may be conducted targeting particular segments of the postal traffic and certain types of services where potential deviations may be expected.

\section{Mr. sc. TOMISLAV KLAK}

E-mail: tomislav.kljak@fpz.hr

Sveučilište u Zagrebu, Fakultet prometnih znanosti

Vukelićeva 4, 10000 Zagreb, Hrvatska

Dr. SC. MARIJAN BOLARIĆ

E-mail: marijan.bolaric@posta.hr

MARIJAN BINIČKI, mr.

E-mail: marijan.binicki@posta.hr

Hrvatska pošta d.d.

Branimirova 4, 10000 Zagreb, Hrvatska

\section{SAŽETAK}

\section{UTJECAJ PROMETA MOBILNIH TELEKOMUNIKACIJA NA RAZVOJ POŠTANSKOG PROMETA}

Temeljna hipoteza rada je da postoji određeni utjecaj između razvoja mobilnih telekomunikacija i razvoja poštanskog prometa. Cilj rada je utvrditi jačinu tog utjecaja kao i prirodu (vrstu) tog utjecaja za slučaj situacije u Republici Hrvatskoj. Prikupljeni su relevantni podaci o broju ostvarenih poštanskih usluga, minutama razgovora unutar, iz i prema mobilnim mrežama, broju poslanih SMS poruka. Međusobna povezanost poštanskog prometa i mobilnih telekomunikacija utvrđivana je modelom višestruke linearne regresije koji je, nakon što je utvrđen, i statistički testiran.

\section{KLUUČNE RIJEČI}

poštanski promet, modeliranje višestrukom linearnom regresijom, promet mobilnih telekomunikacija

\section{LITERATURE}

[1] Nader, F.H., Jimenez, L.A.: Susbtitution Patterns, Background Paper No.5 for Study: Electronic Substitution for Mail, Pitney Bowes, 2005

[2] Kljak, T., Grgurević, I., Vujić, M.: Effects of Implementing e-Services and Telematic Applications in Postal Items Delivery. TST Conference- Advances in Transport Systems Telematics, Katowice, 2008

[3] Main Developments in the Postal Sector (2004-2006), WIK Consult GmbH - May 2006

[4] Pitney Bowes Project: Electronic Substitution for Mail: Models and Results, Myth and Reality. www.postinsight.com, 2006.

[5] UPU: Post 2005: Core Business Scenarios, Bern, 1997

[6] Tabak, P., Kljak, T.: Traffic Flows Model of Postal Items Based on Input-Output Demands in the Public Postal Network: Case Study of Croatia. Promet - Traffic \& Transportation, Vol.21, No.6, 2009.

[7] Izutsu, I., Yamaura, I.: Effect of Telecommunications on Letter Mail Services in Japan. Presentation at the $5^{\text {th }}$ Conference on Postal and Delivery Economics, Helsingør, 1997

[8] Wolak, F.A.: Changes in Household-Level Demand for Postal Delivery Services from 1986 to 1994. Stanford University, 1996

[9] Wolak, F.A.: Electronic Substitution in the HouseholdLevel Demand for Postal Delivery Services. A Communications Cornucopia, Brookings Institution Press, Washington 1998

[10] Santos, R.G., Lagao, S.C.: The Demand for Direct Mail in Portugal. Future Directions in Postal Reform, Kluwer Academic Publishers, Boston, 2001

[11] www.dzs.hr (statistical data)

[12] HAKOM: The Overview of Traffic and Financial Data of the Electronic Communication Market in the Republic of Croatia for the Period 2002 - 2007, www.hakom.hr

[13] Šošić, I.: Vježbe iz statistike, Faculty of Economics and Business - Zagreb, Zagreb, 1998 